American Journal of Environmental Sciences 5 (1): 80-86, 2009

ISSN $1553-345 \mathrm{X}$

(C) 2009 Science Publications

\title{
Effect of Environmental Parameters on hydrogen Production using Clostridium Saccharoperbutylacetonicum N1-4(ATCC 13564)
}

\author{
${ }^{1}$ Walid M. Alalayah, ${ }^{1}$ Mohd Sahaid Kalil, ${ }^{1}$ Abdul Amir H. Kadhum, \\ ${ }^{1}$ Jamaliah Md. Jahim and ${ }^{2}$ Najeeb M. Alauj \\ ${ }^{1}$ Department of Chemical and Process Engineering, Faculty of Engineering and Built \\ Environment, Universiti Kebangsaan Malaysia, 43600 UKM Bangi, Malaysia \\ ${ }^{2}$ Yemen Gas Company, P.O. BOX (13465) Sana'a, Republic of Yemen
}

\begin{abstract}
Problem statement: Hydrogen gas production by Clostridium can be improved by several ways through media formulation, or suitable environment condition. This study was carried out to investigate the environmental factors effects on hydrogen production using Clostridium saccharoperbutylacetonicum N1-4 (ATCC 13564). Approach: The environmental factor studied includes initial substrate concentration, initial medium $\mathrm{pH}$, temperature, sparging nitrogen and addition of $\mathrm{Fe}^{2+}$. Results: The result showed that the best yield of hydrogen produced $\left(\mathrm{Y}_{\mathrm{P} / \mathrm{S}}\right)$ was 3.10 moL (moL glucose $)^{-1}$ when an initial glucose concentration was $10 \mathrm{~g} \mathrm{~L}^{-1}$, initial pH $6.0 \pm 0.2$ at temperature $37^{\circ} \mathrm{C}$. The volume of hydrogen produced was decreased when higher initial glucose concentration was applied. The yield of hydrogen increased when $\mathrm{Fe}^{2+}$ added to medium at concentration of $25 \mathrm{mg} \mathrm{L}^{-1}$. The yield and growth were further increased by sparging with nitrogen gas. Conclusion: It was observed that the best condition for highest hydrogen yield when initial $\mathrm{pH}$ $6.0 \pm 0.2$ at $37^{\circ} \mathrm{C}$ and enhanced by adding ferrous sulfate in anaerobic process.
\end{abstract}

Key words: Hydrogen production, clostridium, anaerobic fermentation, renewable energy

\section{INTRODUCTION}

Hydrogen gas has been suggested as a promising alternative to fossil fuels as an energy carrier for transportation needs. Hydrogen gas has a high energy capacity per unit mass $\left(118.2 \mathrm{~kJ} \mathrm{~g}^{-1}\right)$, in contrast, methane has a relatively lower energy capacity $\left(36.3 \mathrm{~kJ} \mathrm{~g}^{-1}\right)$ and $\mathrm{CO}_{2}$ is released during its combustion in conventional engines. However, most hydrogen is usually produced from stored methane reserves and other nonrenewable materials, resulting in net increases of $\mathrm{CO}_{2}$ in the environment. Shifting a fossil fuel economy to a hydrogen economy offers few environmental advantages if both are based on the net consumption of fossil fuels ${ }^{[1]}$. Thus, it is essential for reducing $\mathrm{CO}_{2}$ emissions that hydrogen production not release a net amount of $\mathrm{CO}_{2}$ into the atmosphere and that the technologies and materials used to produce hydrogen are sustainable.

At present, hydrogen is produced mainly from fossil fuels, biomass and water using chemical or biological processes. The production of hydrogen using mixed anaerobic bacterial cultures has attracted substantial interest recently due to its high conversion and non-polluting nature features as an ideal, clean and sustainable energy in contrast to chemical processes ${ }^{[1-4]}$.

The concept comprises hydrogen production from non-renewable and renewable energy sources, hydrogen transportation and storage, hydrogen utilization and hydrogen safety issues ${ }^{[5]}$. Hydrogen can be produced from non-renewable (coal, nuclear energy) and renewable energy sources (sun, hydro, wind, biomass, tides and so forth) the process of hydrogen production from non-renewable sources still has a chance to release environmentally unfriendly or hazardous wastes. However, renewable energy sources are unlimited and the process of hydrogen production has little impact on the environment ${ }^{[6-8]}$.

Anaerobic fermentation is a promising method of sustainable hydrogen production since organic matter, including waste products, can be used as a feedstock for the process. The highest yields of hydrogen have been reported with strains of clostridia in pure cultures or mixed cultures where clostridia are predominant ${ }^{[1]}$. Therefore, Biological processes evolving hydrogen gas are categorized as a renewable energy source. This has been the subject of basic and applied research for several decades.

Corresponding Author: Walid M. Alalayah, Department of Chemical and Process Engineering, Faculty of Engineering, Universiti Kebangsaan Malaysia, UKM Bangi, Malaysia Tel:+60173355727 
In these biological processes, hydrogen production is carried out by microorganisms; those that can split water into hydrogen and oxygen molecules or those different that can ferment organic materials into hydrogen ${ }^{[9]}$. Based on the metabolic pathways performed by different groups of microorganisms, biological hydrogen production processes can be classified as: biophotolysis of water using algae and cyanobacteria, Photo fermentation of organic materials by photosynthetic bacteria and Dark fermentation of organic materials using fermentative bacteria ${ }^{[10]}$. A novel hybrid system of combining dark and photo fermentations has also been investigated to enhance hydrogen production ${ }^{[11]}$.

Among a large number of microbial species, pure cultures of the genera Entrobactor, Bacillus and Clostridium are the efficient producers of hydrogen ${ }^{[12,13]}$. Glucose is the preferred carbon source for fermentation processes predominantly producing acetic acid or butyric acid and hydrogen gas, according to the following reactions ${ }^{[13,14]}$ :

$$
\begin{aligned}
& \mathrm{C}_{6} \mathrm{H}_{12} \mathrm{O}_{6}+2 \mathrm{H}_{2} \mathrm{O} \rightarrow 2 \mathrm{CH}_{3} \mathrm{COOH}+2 \mathrm{CO}_{2}+4 \mathrm{H}_{2} \\
& \mathrm{C}_{6} \mathrm{H}_{12} \mathrm{O}_{6} \rightarrow \mathrm{CH}_{3} \mathrm{CH}_{2} \mathrm{CH}_{2} \mathrm{COOH}+2 \mathrm{CO}_{2}+2 \mathrm{H}_{2}
\end{aligned}
$$

From the above reactions, it's evident that the maximum of $4 \mathrm{~mol} \mathrm{H}_{2} / \mathrm{mol}$ glucose could be obtained when acetic acid is the by product and half of this yield per molecule of glucose is obtained with butyrate as the fermentation end product.

Since very few studies were conducted on hydrogen production using Clostridium saccharoperbutylacetonicum N1-4 (ATCC 13564) (here after referred to as CS N1-4), further work is needed on this field to enhance yield of hydrogen. Since number of studies were conducted using this microorganism for fermentative Acetone, Butanol and Ethanol (ABE) from defined media. This research was conducted to investigate the effects of size inoculum, initial substrate concentration, initial medium $\mathrm{pH}$, temperature, $\mathrm{Fe}^{2+}$ addition and nitrogen sparing on hydrogen production.

\section{MATERIALS AND METHODS}

Microorganism and pre culture development: CS N1-4 culture stock was obtained from a culture collection maintained at the Chemical Engineering Department, UKM. The culture stock was grown on TYA agar medium, Single colonies three to five of CS N1-4 from TYA agar culture were transferred anaerobically into $10 \mathrm{~mL} 15 \%$ Potato-Glucose (PG) containing (150 g fresh mesh potato, $0.5 \mathrm{~g}\left(\mathrm{NH}_{4}\right)_{2} \mathrm{SO}_{4}$, $10 \mathrm{~g}$ glucose and $3 \mathrm{~g} \mathrm{CaCO}_{3}$ ) medium and these were incubated anaerobically condition at $30^{\circ} \mathrm{C}$ for $30 \mathrm{~h}^{[15]}$. A $1 \mathrm{~mL}$ aliquot of this culture was transferred into $9 \mathrm{~mL}$ fresh PG medium, incubated in the same conditions at $37^{\circ} \mathrm{C}$ for $18 \mathrm{~h}$ and used as inoculum.

Culture media: A solution of $15 \%$ PG medium per liter of distilled water was used as a growth medium for inoculum. This medium was incubated in boiling water for $1 \mathrm{~h}$ and then filtered with cotton cloth. The filtrate was sterilized in an autoclave at $121^{\circ} \mathrm{C}$ for $15 \mathrm{~min}$. Tryptone-Yeast Extract- Acetate (TYA) medium was used for the pre-culture and main culture and the composition of this medium per liter of distilled water ${ }^{[16]}$ was used. The medium contains 40 g glucose, $2 \mathrm{~g}$ yeast extract, $6 \mathrm{~g}$ Bact-Tryptone, $3 \mathrm{~g}$ ammonium acetate, $10 \mathrm{mg} \mathrm{FeSO} 4.7 \mathrm{H}_{2} \mathrm{O}, 0.5 \mathrm{~g} \mathrm{KH}_{2} \mathrm{PO}_{4}$ and $0.3 \mathrm{~g}$ $\mathrm{MgSO}_{4} \cdot 7 \mathrm{H}_{2} \mathrm{O}$ per liter of distilled water. The concentration of glucose was varied from 1-40 $\mathrm{g}$ in this experiment to investigate the substrate effect on hydrogen production. The $\mathrm{pH}$ of the TYA medium was adjusted to $6 . \pm 0.2$ with $5 \mathrm{M} \mathrm{NaOH}$ and sterilized at $121^{\circ} \mathrm{C}$ for $15 \mathrm{~min}^{[17]}$. TYA agar medium was prepared by adding $15 \mathrm{~g}$ Agar Bacteriological No.1.

Experimental procedure: Batch culture was carried out at $30^{\circ} \mathrm{C}$ in a $500 \mathrm{~mL}$ Duran bottle. At the top of the bottle there was an inlet for the medium and outlets for gases. The fermentation temperature was maintained at $37^{\circ} \mathrm{C}$ using a water bath. Initial glucose concentrations of $1,5,10,20$ and $40 \mathrm{~g} \mathrm{~L}^{-1}$ were evaluated. The initial $\mathrm{pH}$ was adjusted to 6.0 during fermentation with $5 \mathrm{M}$ $\mathrm{NaOH}$ and sterilized at $121^{\circ} \mathrm{C}$ for $15 \mathrm{~min}$. Aliquots containing $10 \%(\mathrm{v} / \mathrm{v})$ seed culture of CS N1-4 grown for $30 \mathrm{~h}$ in $\mathrm{PG}$ and transferred to Petri dish medium agar for $48 \mathrm{~h}$, were used as the inoculum. The evolved gas mixture from the reactor, containing both hydrogen and carbon dioxide was passed through $5 \mathrm{M} \mathrm{KOH}$ solution to absorb most of carbon dioxide ${ }^{[18]}$ and then subjected to analysis.

Analysis methods: The composition of the gas was analyzed using gas chromatography (SRI 8610C, USA), equipped with a helium ionization detector $(15 \mathrm{~m}$ length). The temperatures of the oven, injector and detector were 50,100 and $200^{\circ} \mathrm{C}$ respectively. The cell biomass concentration was estimated as the Dry Weight Cell (DWC) by spectrophotometrically measuring the optical density at the $660 \mathrm{~nm}$ wavelength and then relating the optical density to DWC. The reducingsugar (glucose) content of the medium was also estimated using the Miller method ${ }^{[19]}$. The glucose 
concentration in the medium was measured using the 3 , 5 dinitrosalicylic acid (DNS) assay for total reducing sugars. A $1 \mathrm{~mL}$ aliquot of the sample and $2 \mathrm{~mL}$ aliquot of the DNS reagent mixture were mixed together in a test tube. The mixtures were placed in a boiling water bath for $5 \mathrm{~min}$ and then diluted with $10 \mathrm{ml}$ of distilled water. The absorbencies at OD550nm for all samples were recorded and the glucose concentration was calculated from a standard curve.

\section{RESULTS}

Effect of inoculum size: The effect of the inoculum sizes of 5,10 and $20 \%(v / v)$ were investigated in a $100 \mathrm{~mL}$ culture containing TYA medium at $37^{\circ} \mathrm{C}$. Table 1 show that the bacteria grew fairly well in the TYA medium with $10 \%$ inoculum. The absorbance optical densities at $660 \mathrm{~nm}$ were $0.945,1.361$ and 1.031 for the 5, 10 and $20 \%$ cases respectively.

Effect of initial glucose concentration: effect of glucose content in the culture media on fermentation is presented in Table 2. The highest yield of hydrogen was observed when initial glucose concentration was $10 \mathrm{~g} \mathrm{~L}^{-1}$ with consumption of $81.8 \%$, as shown in Fig. 1a. The best yield of hydrogen production on varying glucose concentration with time was $10 \mathrm{~g} \mathrm{~L}^{-1}$ as shown in Fig. 1b and this decreased with increasing glucose concentration.

Effect of initial medium pH: Result shows that the maximum rate of hydrogen production was measured at initial $\mathrm{pH} 6.0 \pm 0.2$, while the min rate of hydrogen production was recorded at initial $\mathrm{pH} 4.0 \pm 0.2$ as shown in Fig. 2a. As shown in Fig. 2b, lower consumption was observed at an initial $\mathrm{pH}$ of $4.0 \pm 0.2$ and higher consumption was observed with an initial $\mathrm{pH}$ of $6.0 \pm 0.2$.

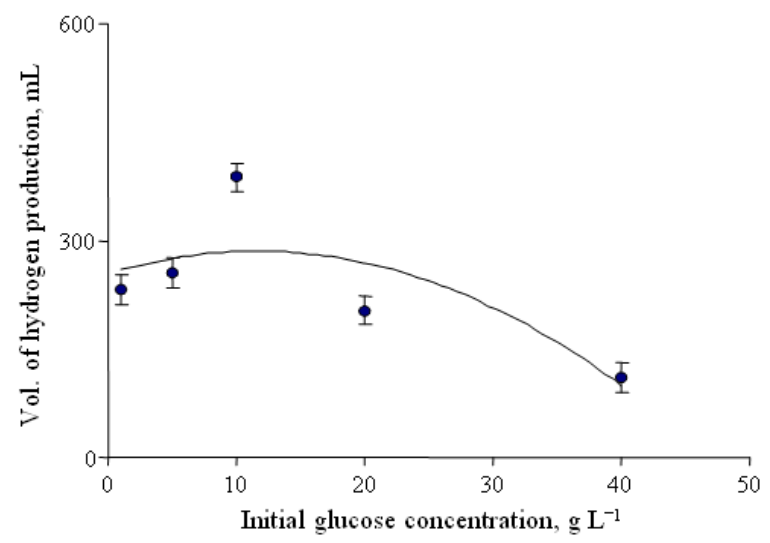

Fig. 1a: Hydrogen production at varying glucose concentrations for $48 \mathrm{~h}$
The profile of biomass and glucose concentration during the course of growth of CS N1-4 in a batch system is shown in Fig. 2c. The biomass was increased with time during the experiment, while the glucose concentration decreased during time for $10 \mathrm{~g} \mathrm{~L}^{-1}$ glucose.

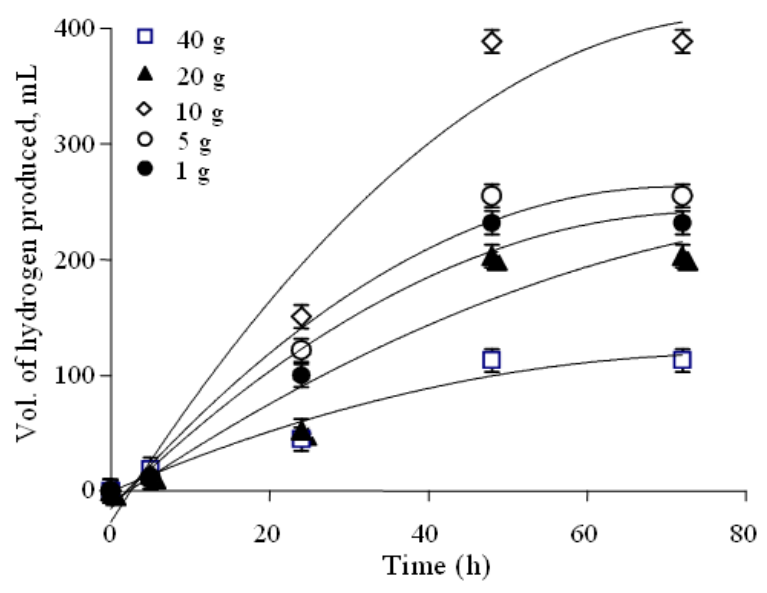

Fig. 1b: Hydrogen production profiles of various initial glucose concentrations as a function of time

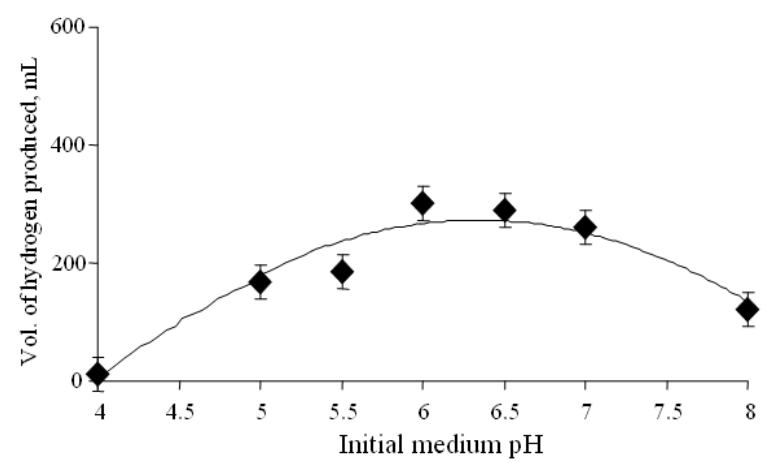

Fig. 2a: Effect of initial medium $\mathrm{pH}$ on hydrogen production for $48 \mathrm{~h}$

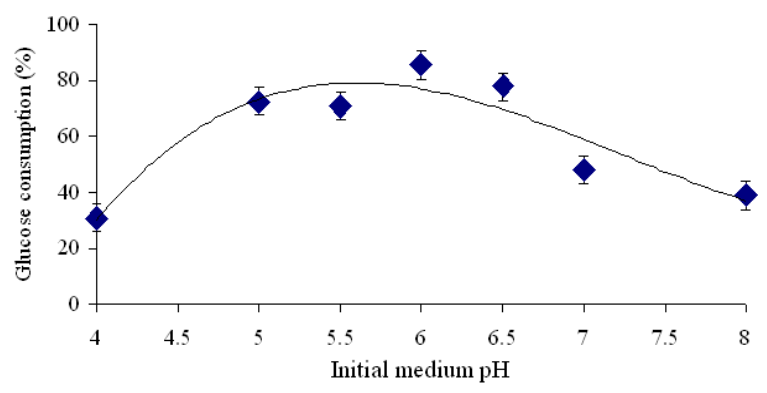

Fig. 2b: Initial medium $\mathrm{pH}$ and glucose consumption percentage 
Am. J. Environ. Sci., 5 (1): 80-86, 2009

Table 1: Effect of inoculum size by CS N1-4

\begin{tabular}{|c|c|c|c|}
\hline Parameters & Inoculum $5 \%(\mathrm{v} / \mathrm{v})$ & Inoculum $10 \%(\mathrm{v} / \mathrm{v})$ & Inoculum $20 \%(\mathrm{v} / \mathrm{v})$ \\
\hline Final $\mathrm{pH}$ & 4.4000 & 4.5800 & 4.6500 \\
\hline Specific growth rate, $h-1(\mu)$ & 0.0192 & 0.0541 & 0.0330 \\
\hline Initial growth as measured by OD $660 \mathrm{~nm}$ & 0.0320 & 0.0560 & 0.0610 \\
\hline Final growth as measured by OD $660 \mathrm{~nm}$ & 0.9450 & 1.3610 & 1.0310 \\
\hline Max. Time $\mathrm{H}_{2}$ produced & 32.0000 & 28.0000 & 22.0000 \\
\hline $\mathrm{Y}_{\mathrm{p} / \mathrm{s}} \mathrm{mL} \mathrm{H}_{2}(\mathrm{~g} \text { glucose })^{-1}$ & 203.0000 & 290.0000 & 232.0000 \\
\hline
\end{tabular}

Table 2: Effect of initial glucose concentration on hydrogen production by CS N1-4

\begin{tabular}{lllll}
\hline $\begin{array}{l}\text { Initial glucose, } \\
\mathrm{g} \mathrm{L}^{-1} \text { concentration }\end{array}$ & $\begin{array}{l}\text { Duration of gas } \\
\text { production, } \mathrm{h}\end{array}$ & $\begin{array}{l}\text { Volume of Hydrogen } \\
\text { Production, } \mathrm{mL}\end{array}$ & $\begin{array}{l}\text { Residual glucose } \\
\text { concentration }\end{array}$ & $\begin{array}{l}\text { Glucose } \\
\text { consumption (\%) }\end{array}$ \\
\hline 1 & 24 & 232 & 0.13 & 87.00 \\
5 & 34 & 255 & 0.90 & 82.00 \\
10 & 48 & 388 & 1.82 & 81.80 \\
20 & 48 & 203 & 8.20 & 59.00 \\
40 & 49 & 110 & 26.50 & 33.75 \\
\hline
\end{tabular}

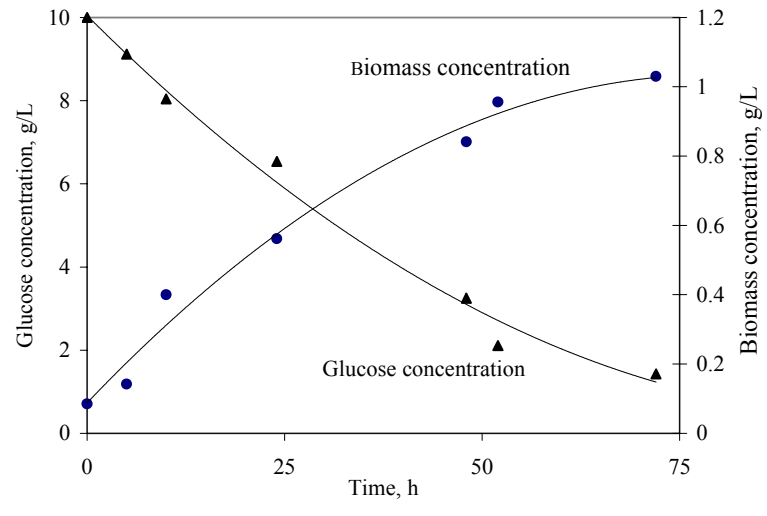

Fig. 2c: Profile of biomass concentration and glucose consumed during fermentative in TYA medium.

Effect of temperature: The effect of temperature on the rate of hydrogen production was also investigated in this study. The range of temperatures studied was from $25-40^{\circ} \mathrm{C}$. The initial glucose concentration and initial $\mathrm{pH}$ were $10 \mathrm{gL}^{-1}$ and $6.0 \pm 0.2$, respectively. The effect of temperature on fermentation medium for hydrogen production is shown in Fig. 3. It was observed that the rate of hydrogen production increased with increasing temperature. The best production was recorded at $37^{\circ} \mathrm{C}$. Further increases in temperature resulted in a subsequent reduction of hydrogen production. When comparing this result with previous study on other microorganisms, it was found that the maximum hydrogen production was at $38^{\circ} \mathrm{C}^{[24]}, 40.5^{\circ} \mathrm{C}^{[25]}$, $40^{\circ} \mathrm{C}^{[20]}$ and $37^{\circ} \mathrm{C}^{[23]}$.

Effect of nitrogen sparging: Since CS N1-4 is anaerobe bacteria precaution was controlled to minimize the introduction of oxygen into the culture after medium sterilization and during inoculation ${ }^{[17]}$.

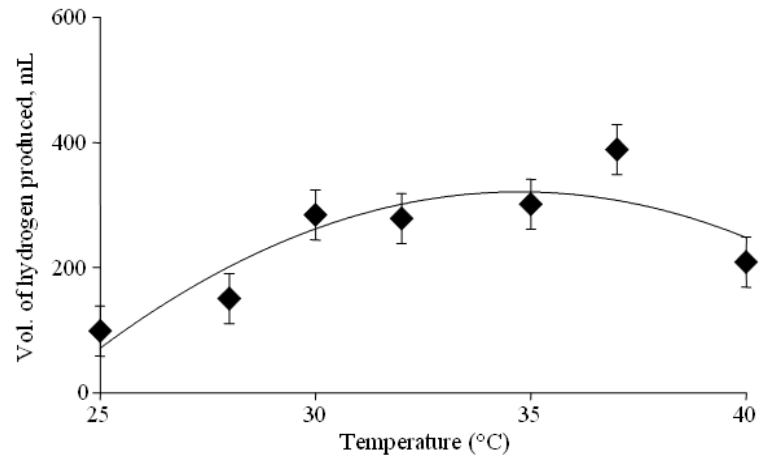

Fig. 3: Effect of temperature on the hydrogen production by CS N1-4

Investigators have used various strategies to enhance anaerobic fermentation environment including used an anaerobic chamber for inoculation, maintenance of constant stream nitrogen gas over the culture headspace during fermentation or until the microorganism is capable of producing enough metabolic gases to fill up the culture headspace. Figure 4 shows the time course of biomass concentration, glucose consumption and hydrogen production. Biomass growth without initial nitrogen sparging resulted in longer lag phase as shown in Fig. 4a, while as shown in Fig. 4b the residual glucose with initial nitrogen sparing was observed to be more suitable than without sparging. Less hydrogen production without initial nitrogen sparging as shown in Fig. $4 \mathrm{c}$ was observed.

Effect of $\mathrm{Fe}^{2+}$ concentrations: In hydrogen production fermentation processes several researcher reported on the effect of iron on the bacterial metabolism. It was reported that iron- sulfur has effect on protein functions primarily as an electron carrier and is involved in pyruvate oxidation to acetyl-CoA, $\mathrm{CO}_{2}$ and $\mathrm{H}_{2}$. 


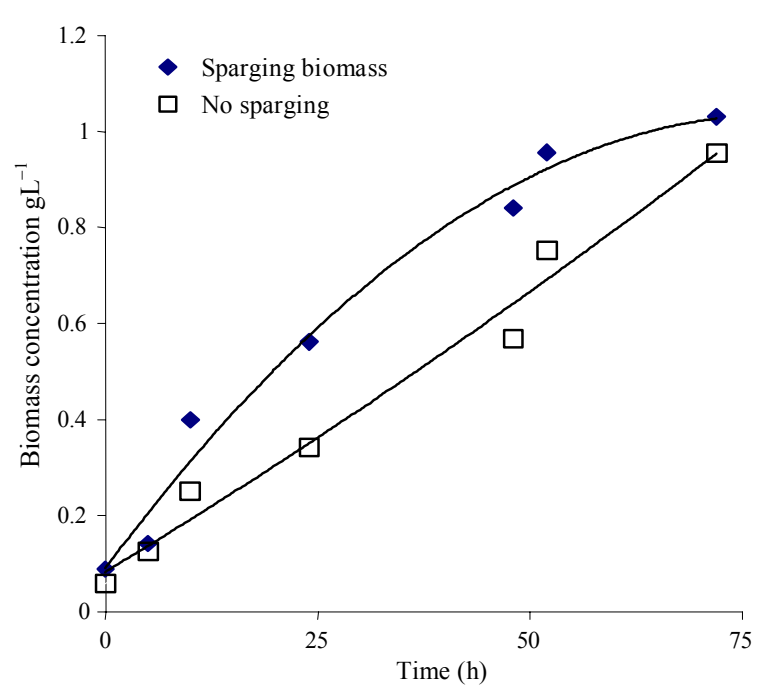

(a)

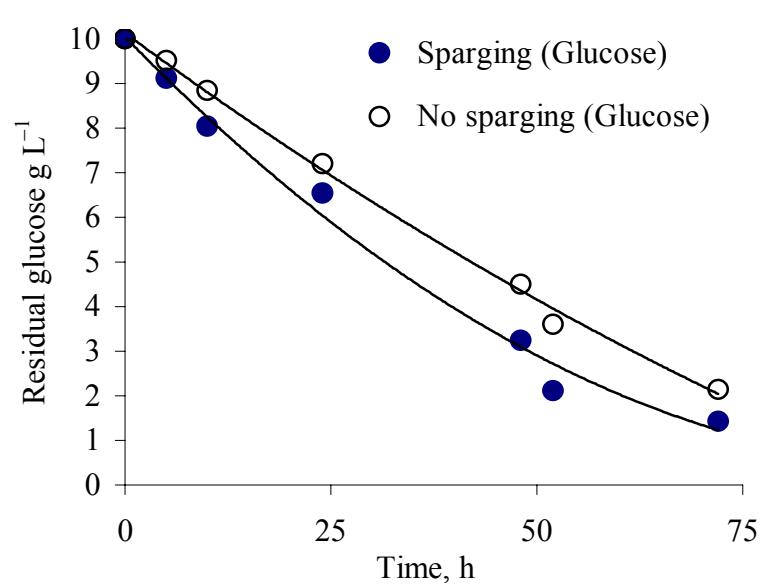

(b)

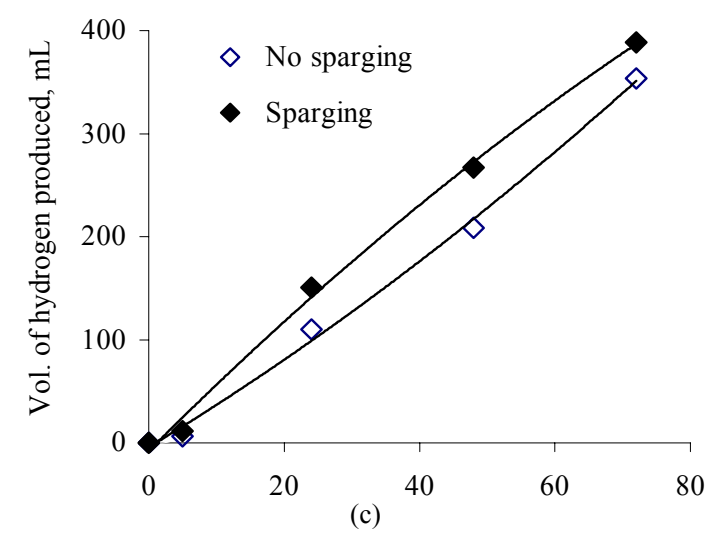

Fig. 4: Effect of initial nitrogen sparging on: (a): Biomass growth; (b): Glucose consumption and (c): Hydrogen production in batch reactor using CSN1-4
Table 3: Effect of iron concentration on hydrogen production by CS

\begin{tabular}{|c|c|c|c|c|c|c|}
\hline \multicolumn{7}{|c|}{$\mathrm{N} 1-4$} \\
\hline $\begin{array}{l}\mathrm{FeSO}_{4} . \\
7 \mathrm{H}_{2} \mathrm{O} \text { conc. } \\
\left(\mathrm{mg} \mathrm{L}^{-1}\right)\end{array}$ & $\begin{array}{l}\text { Duration } \\
\text { of } \\
\text { prod., h }\end{array}$ & $\begin{array}{l}\text { Biomass } \\
\text { (OD at } \\
600 \mathrm{~nm})\end{array}$ & $\begin{array}{l}\text { Glucose } \\
\text { consumption } \\
\text { (\%) }\end{array}$ & $\begin{array}{l}\text { Final } \\
\mathrm{pH}\end{array}$ & $\begin{array}{l}\mathrm{H}_{2} \\
\text { prod., } \\
\text { mL }\end{array}$ & $\begin{array}{l}\text { Prod. } \\
\text { rate } \\
\left(\mathrm{mL} \mathrm{h}^{-1}\right)\end{array}$ \\
\hline 1 & 48 & 1.01 & 50 & 4.95 & 133.4 & 2.78 \\
\hline 5 & 41 & 1.10 & 54 & 5.12 & 174.0 & 4.24 \\
\hline 10 & 38 & 1.13 & 65 & 4.78 & 197.2 & 5.18 \\
\hline 15 & 35 & 1.15 & 66 & 4.70 & 208.8 & 5.95 \\
\hline 20 & 30 & 1.19 & 69 & 4.80 & 220.4 & 7.34 \\
\hline 25 & 30 & 1.23 & 70 & 4.55 & 232.0 & 7.73 \\
\hline 30 & 25 & 1.30 & 62 & 4.51 & 157.4 & 6.29 \\
\hline 40 & 23 & 1.35 & 55 & 4.33 & 140.0 & 6.08 \\
\hline 100 & 18 & 1.38 & 45 & 4.20 & 104.0 & 5.77 \\
\hline
\end{tabular}

Iron could induce metabolic change and be involved in $\mathrm{Fe}-\mathrm{S}$ and non $\mathrm{Fe}-\mathrm{S}$ proteins operating in hydrogenase ${ }^{[27]}$. The addition of iron sulfate has some effects on growth and the rate of hydrogen production. In this work the effect of iron on hydrogen production, ferrous sulphate heptahydrate $\left(1-100 \mathrm{mg} \mathrm{L}^{-1}\right)$ was investigated. Hydrogen production and production rate with the growth parameters were shown in Table 3. It was observed that the best condition for highest hydrogen yield when initial $\mathrm{pH} 6.0 \pm 0.2$ at $37^{\circ} \mathrm{C}$ and enhanced by adding ferrous sulfate in anaerobic process. Highest yield of hydrogen was observed to be collected when $\mathrm{FeSo}_{4} .7 \mathrm{H}_{2} \mathrm{O}$ concentration $25 \mathrm{mg} \mathrm{L}^{-1}$.

\section{DISCUSSION}

In Table 1, these results reflect that a higher hydrogen yield, doubling time and specific growth rate were observed when the inoculum size was $10 \%$.

The initial glucose concentration plays an important role in the quality and rate of hydrogen production during the fermentation at the relatively low initial glucose levels. The rate of fermentation was low according to the law of mass action as reported in the literature $^{[13,20]}$.

$\mathrm{pH}$ is an important controlling factor of anaerobic fermentation processes. Many researchers have reported that $\mathrm{pH}$ could affect the metabolic pathway of dark fermentation in pure culture ${ }^{[3,21,22,26]}$. A set of tests in this study was performed by varying the initial $\mathrm{pH}$ from $4.0 \pm 0.2-8.0 \pm 0.2$ and the result was in the range with previous work.

In effect of temperature the result was in agreement with the results reported by references ${ }^{[13,23]}$ using other microorganisms. By comparing this result with previous study on other microorganisms, it was found that the maximum hydrogen production was at $38^{\circ} \mathrm{C}^{[24]}$, $40.5^{\circ} \mathrm{C}^{[25]}, 40^{\circ} \mathrm{C}^{[20]}$ and $37^{\circ} \mathrm{C}^{[23]}$. 


\section{CONCLUSION}

This study investigated the effects of environmental factors on formative hydrogen production using CS N1-4 in batch reactor. The best concentration of glucose for a higher production of hydrogen was studied and the highest yield of hydrogen was $3.10 \mathrm{~mol}$ (mol glucose) $)^{-1}$ when an initial glucose concentration is $10 \mathrm{~g} \mathrm{~L}^{-1}$ as a substrate in TYA medium while by increasing the initial substrate the hydrogen production rate decreased. A set of tests in this study was performed at varying initial $\mathrm{pHs}$ from $4.0 \pm 0.2$ $8.0 \pm 0.2$. The highest rate of hydrogen production was at initial $\mathrm{pH} 6.0 \pm 0.2$, while the lowest rate of hydrogen production was recorded at initial $\mathrm{pH} 4.0 \pm 0.2$. The effect of temperature of fermentation medium on hydrogen production rate was studied and the best production was recorded at $37^{\circ} \mathrm{C}$. It was observed that the best condition for highest hydrogen yield when initial $\mathrm{pH} \quad 6.0 \pm 0.2$ at $37^{\circ} \mathrm{C}$ and enhanced by adding ferrous sulfate in anaerobic process. The yield of hydrogen was observed to increase by adding $\mathrm{Fe}^{2+}$ concentration $25 \mathrm{mg} \mathrm{L}^{-1}$ and the yield of hydrogen enhanced further by sparging the fermentation medium with nitrogen gas to eliminate any oxygen in the system.

\section{ACKNOWLEDGMENT}

The researchers thank Prof. Dr Yoshino Sadazo, Biotechnology laboratory Kyushu University, Japan, who provided us with CS N1-4. This research was supported by UKM- OUP-KPB-32-162/2008 grant.

\section{REFERENCES}

1. Wooshin, P., H.H. Seung, E.O. Sang, E.L. Bruce and K. Ins, 2006. Removal of headspace $\mathrm{CO}_{2}$ increases biological hydrogen production. Env. Sci. Tech., Am. Chem. Soc., 39: 4416-4420. DOI: $10.1021 / \mathrm{es} 048569 \mathrm{~d}$.

2. Dunn, S., 2002. Hydrogen futures: Toward a sustainable energy system, Int. J. Hydrogen Energy, 27: 235-264. DOI: 10.1016/S03603199(01)00131-8.

3. Logan, B.E., Z. Husen and A.B. Mary, 2006. Biological hydrogen production by Clostridium acetobutylicum in an unsaturated flow reactor. Int. J. Water Res., 40: 728-734. DOI: 10.1016/J.WATRES. 2005.11.041.

4. Khanal, S.K., W.H. Chen, L. Li and S. Sung, 2006. Biohydrogen production in continuousflow reactor using mixed microbial culture. Int. J. Water Environ. Res., 78: 110-117. DOI: 10.2175/106143005X89562.
5. Lay, J.J., K.S. Fan, J.I. Chang and C.H. Ku, 2003. Influence of chemical nature of organic wastes on their conversion to hydrogen by heat-shock digested sludge. Int. J. Hydrogen Energ., 28: 1361-1367. DOI: $10.1016 / \mathrm{S} 0360-3199$ (03)00027-2.

6. Goltsov, V.A., T.N. Veziroglu and L.F. Goltsova, 2006. Hydrogen civilization of the future a new conception of the IAHE. Int. J. Hydrogen Energ., 31: 153-159. DOI: 10.1016/J.IJHYDENE.2005.04.045.

7. Da Silva E.P., A.J.M. Neto, P.F.P. Ferreira, J.C. Camargo, F.R. Apolinario and C.S. Pinto, 2005. Analysis of hydrogen production from combined photovoltaics, wind energy and secondary hydroelectricity supply in Brazil. Int. J. Solar Energ., 78: 670-677. DOI: 10.1016/J.SOLENER.2004.10.011.

8. Sherif, S.A., F. Barbir and T.N. Veziroglu, 2005. Wind energy and the hydrogen economy. Solar Energ., 78 : 647-660. DOI: 10.1016/J.SOLENER.2005.01.002.

9. Tsai, W.T., 2005. Current status and development policies on renewable energy technology research in Taiwan. Renew. Sustain. Energ. Rev., 9: 237-253. DOI: 10.1016/J.RSER.2004.03.003.

10. Levin, D.B., L. Pit and M. Love, 2004. Biohydrogen production: Prospects and limitations to practical application. Int. J. Hydrogen Energ., 29: $\quad 173-185$. DOI: $10.1016 / \mathrm{S} 0360-$ 3199(03)00094-6.

11. Hallenbeck, P.C. and J.R. Benemann, 2002. Biological hydrogen production: Fundamentals and limiting processes. Int. J. Hydrogen Energ., 27: $1185-1193 . \quad$ DOI: $10.1016 / \mathrm{S} 0360-$ 3199(02)00131-3.

12. Das, D. and T.N. Veziroğlu, 2001. Hydrogen production by biological processes: A survey of literature. Int. J. Hydrogen Energ., 26: 13-28. DOI: 10.1016/S0360-3199(00)00058-6.

13. Nandi, R. and S. Sengupta, 1998. Microbial production of hydrogen: An overview. Crit. Rev. Microbial, 24 : 61-84. DOI: 10.1080/10408419891294181.

14. Kaushik, N., K. Anish and D. Debabrata, 2006. Effect of some environmental parameters on fermentive hydrogen production. Can. J. Microbiol., 52: 525-535. DOI: 10.1139/w06-005.

15. Claassen, P.A.M., J.B. van Lier, A.M. Lopez Contreras, E.W.J. van Niel, L. Sijtsma, A.J.M. Stams, S.S. de Vries and R.A. Weusthuis 1999. Utilisation of biomass for supply of energy carriers. Applied Microbial. Biotechnol., 52: 741-755. DOI: 10.1007/s002530051586. 
16. Saleha, S., M.S.H. Kalil and M.W.W. Yusoff, 2006. Production of Acetone, Butanol and Ethanol (ABE) by Clostridium saccharoperbutylacetonicum N1-4 with different immobilization systems. Pak. J. Biol. Sci., 9: 1923-1928. http://www.doaj.org/ doaj?func $=$ abstract\&id $=187176$.

17. Kalil, M.S., Y. Pang, Y. Sadazo, A.R. Rakmi and M. Wan, 2003. Direct fermentation of palm oil mill effluent to acetone-butanol-ethanol by solvent producing clostridia. Pak. J. Biol. Sci., 6: 1273-1275. http://www.doaj.org/ doaj?func $=$ abstract\&id $=185881$.

18. Cirilo, N.H., C. Edward, M.B. Carmen, C. Octavio, A.M.M. Miguel, P.F. Gabrie, A.H.C. Manuel and I. Ayaaki, 2008. Bioconversion of industrial wastewater from palm oil processing to butanol by Clostridium saccharoperbutylacetonicum N1-4 (ATCC 13564). J. Cleaner Prod., 16: 632-638. DOI: 10.1016/j.jclepro.2007.02.005.

19. Miller, G.L., 1959. Use of dinitrosalicylic acid reagent for determination of reducing sugar. Anal. Chem., 31: 426-429. DOI: 10.1021/ac60147a030

20. Fabiano, B. and P. Perego, 2002. Thermodynamic study and optimization of hydrogen production by Enterobacter aerogenes. Int. J. Hydrogen Energ., 27: $149-156$. DOI: 10.1016/S03603199(01)00102-1.

21. Van, G.S., S. Sung and J.J. Lay, 2001. Biohydrogen production as a function of $\mathrm{pH}$ and substrate concentration. Environ. Sci. Technol., 35: 4726-4730. DOI: 10.1021/es001979rS0013936X(00)01979-9.
22. Wang, C.C., C.W. Chang, C.P. Chu, D.J. Lee, B.V. Chang and C.S. Liao, 2003. Producing hydrogen from wastewater sludge by Clostridium bifermentans. J. Biotechnol., 102: 83-92. DOI: 10.1016/S0168-1656(03)00007-5.

23. Kumer, N. and D. Das, 2000. Emhancement of hydrogen production by Enterobacter cloacae IITBT 08. Process. Biochem., 35: 589-593. DOI: 10.1016/S0032-9592(99)00109-0.

24. Yokoi, H., T. Ohkawara, J. Hirose, S. Hayashi and Y. Takasaki, 1995. Charactarastics of hydrogen production by aciduric Enterobacter aerogenes strain HQ-39. J. Bioeng., 80: 571-574. DOI: 10.1016/0922-338X(96)87733-6.

25. Tanisho, S., Y. Suzuki, N. Wakao, 1987. Fermentative hydrogen evolution by Enterobacter aerogenes strain E82005. Int. J. Hydrogen Energ., 12: 623-627. http://cat.inist.fr/ ?aModele $=$ afficheN\&cpsidt $=7404259$.

26. Ferchichi, M., E. Crabbe, W. Hintz, G.H. Gil and A. Almadidy, 2005. Influence of culture parameters on biological hydrogen production by C. saccharoperbutylacetonicum ATCC 27021. World J. Microbiol. Biotechnol., 21: 855-862. DOI: $10.1007 / \mathrm{s} 1$ 1274-004-5972-0.

27. Lee, Y., J. Miyahara and T. Noike, 2001. Effect of iron concentration on hydrogen fermentation. Bioresour. Technol., 80: 227-231. DOI: 10.1016/S0960-8524(01)00067-0. 